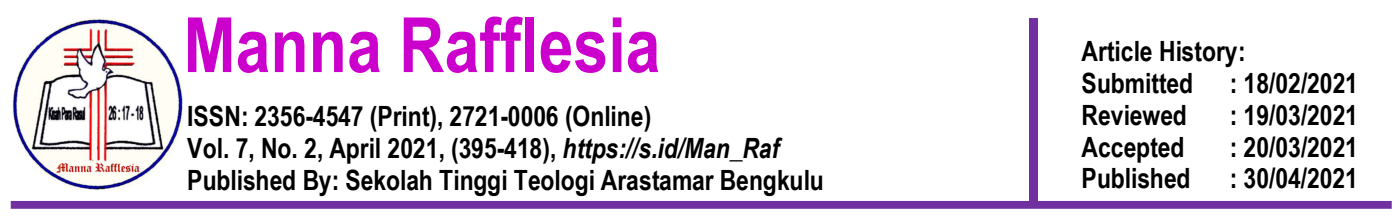

\title{
MAKNA UNGKAPAN YANG SULUNG DALAM KOLOSE 1:15 SEBAGAI TANGGAPAN TERHADAP PEMAHAMAN KRISTOLOGI SAKSI YEHUWA
}

\author{
Jacob Timisela ${ }^{1}$ ) \\ Sekolah Tinggi Teologi Baptis Jakarta ${ }^{1}$ \\ *)Email Correspondence: jacobtimisela@gmail.com
}

\begin{abstract}
The mid-19th century until now Christians are confused and troubled by the movements and teachings of the Witnesses who have undermined the Superiority of Christ. In particular when they interpret the word prototokos in Colossians 1:15 which is very different, even contrary to Christian understanding and beliefs in general. The results of this study found that there are differences in the basic and background interpretations used by Jehovah's Witnesses with the basis and background for the interpretation of Christians in general of the word prototokos in Colossians 1:15. Jehovah's Witnesses use the word qanah (קנח) from Proverbs 8: 22,25 as the basis and background for the interpretation of the word prototokos in Colossians 1:15.
\end{abstract}

Keywords: Study, prototokos, Christology, Jehovah's Witnesses.

\begin{abstract}
Abstrak: Pada pertengahan abad ke-19 hingga sekarang umat Kristen seringkali dibingungkan dan diresahkan dengan berbagai gerakkan dan ajaran Saksi- Saksi Yehuwa yang dinilai telah merendahkan Superioritas Kristus. Secara khusus ketika mereka menafsirkan kata prōtotokos dalam Kolose 1:15 yang sangat berbeda, bahkan dinilai sangat bertentangan dengan pemahaman dan keyakinan kristen secara umum. Untuk mencapai tujuan penelitian dan penulisan, maka penelitian menggunakan metode kualitatif untuk kajian biblika dengan menggunakan pendekatan eksegesis terhadap kata 'yang sulung atau prōtotokos' dalam Kolose 1:15. Hasil dari penelitian ini menemukan adanya perbedaan dasar dan latar belakang penafsiran yang digunakan oleh Saksi-saksi Yehuwa dengan dasar dan latar belakang penafsiran umat kristen pada umumnya terhadap kata 'yang sulung atau prōtotokos' dalam Kolose 1:15.
\end{abstract}

Kata kunci: Studi, prōtotokos, Kristologi, Saksi Yehuwa.

\section{PENDAHULUAN}

Berbagai fenomena ajaran dan pandangan teologi yang muncul seringkali

dapat berpengaruh bagi pemahaman dan kehidupan sebagian besar umat Kristen.

Pengaruh tersebut ada yang bermanfaat untuk meneguhkan ajaran dan iman kristiani, namun di pihak lain seringkali memunculkan isu-isu teologis yang dapat meresahkan umat kristiani, karena dinilai sebagai ajaran yang menyimpang dari 
kebenaran Alkitab yang sesungguhnya. John Stott menyatakan bahwa, berbagai pandangan yang muncul dalam beberapa dasawarsa terakhir ini, sebagian meresahkan iman dan sebagian harus dipertanyakan keabsahan landasannya. ${ }^{1}$

Sebagian pengajaran tentang konsep Kristologi yang telah berkembang dari masa ke masa seringkali dipandang sebagai bentuk penolakan dan perendahan terhadap pribadi dan martabat Yesus Kristus. ${ }^{2}$ Secara khusus adanya ajaran Kristologi yang disebarkan oleh aliran Saksi-saksi Yehuwa yang dinilai sangat bertentangan dengan ajaran Kristologi dan keyakinan umat Kristen secara umum, sehingga banyak menimbulkan masalah atau keresahan bagi umat Kristen, karena mereka tidak menerima Kristus sebagai pribadi illahi. ${ }^{3}$ Gerakkan Saksisaksi Yehuwa dinilai sebagai penyimpangan dalam agama Kristen Protestan atau sesat ibarat kelompok Ahmadiyah. ${ }^{4}$ Inilah yang menyebabkan gereja- gereja di Indonesia tidak memiliki hubungan dengan kelompok Saksi- saksi Yehuwa ${ }^{5}$

Salah satu ajaran Kristologi kelompok ini sejak lama didasarkan pada penafsiran kata 'prōtotokos' (yang sulung) dalam Kolose 1: 15. Menurut mereka, kata "prōtotokos" sebagai bukti bahwa Yesus adalah ciptaan pertama dan bukan sang pencipta. Menurut mereka, ada masa dimana pernah sekali waktu Allah (Yehuwa) itu berada dalam kesendirian. Kemudian Allah menggunakan kuasaNya untuk menciptakan yang tak terselami guna membentuk suatu pribadi roh yang hidup dan cerdas yang bernama Yesus Kristus. Yesuslah sebagai 'awal dari ciptaan Allah' dan karena itu Ia disebut sebagai satu-satunya putra Allah yang

\footnotetext{
1 John Stott, Kristus Yang Tiada Tara (Surabaya: Momentum, 2007), 5.

2 Craig A. Evans, Merekayasa Yesus (Yogyakarta: ANDI, 2007), 111-113.

3 Tim Redaksi LLB, Bagaimana Menghadapi Saksi Yehuwa, t.t., 7.

4 Arifuddin Ismail, "The Contradiction of the Presence of Jehovah's Witnesess as Christian Denomination in Yogyakarta," Analisa 19, no. 2 (7 Desember 2012): 171, https://doi.org/10.18784/analisa.v19i2.164.

5 Herlianto, Saksi-Saksi Yehuwa; Tamu tak diundang yang rajin berkunjung ke rumah-rumah (Bandung: Kalam Hidup, 2004), 26.
} 
sulung atau yang pertama kali diciptakan dari antara semua ciptaan, ${ }^{6}$ sebelum Adam diciptakan. ${ }^{7}$ Bahkan Ia telah ada sebelum makhluk-makhluk roh dan alam semesta ini diciptakan. ${ }^{8}$ Kristus adalah pribadi kedua yang terbesar dalam alam semesta. Kemudian disebut sebagai orang pertama dana satu-satunya yang langsung diciptakan oleh Bapa-Nya. ${ }^{9}$ Karena itu Yehuwa disebut Bapa karena Ia adalah Sang Pencipta, dan karena Yesus diciptakan oleh Allah maka Ia disebut Putra Allah. ${ }^{10}$ Kelompok Saksi Yehuwa beranggapan bahwa, karena status Yesus sebagai ciptaan membuat kedudukan diri Yesus sendiri lebih rendah daripada Allah Yehuwa. ${ }^{11}$ Karena itu para penganut Saksi Yehuwa tidak memberikan penyembahan kepada Yesus sebagai Allah yang benar dan sejati. Juga tidak mengimaninya sebagai Tuhan atau Allah Yang Mahakuasa. ${ }^{12}$

Karena itu tujuan yang hendak dicapai dalam penelitian dan penulisan ini yaitu, pertama, untuk menjelaskan arti dan latar belakang penggunaan kata 'yang sulung atau prōtotokos' oleh rasul Paulus dalam Kolose 1:15. Kedua, untuk menjelaskan apa yang melatarbelakangi dan mendasari penafsiran Saksi-saksi Yehuwa terhadap kata 'yang sulung atau prōtotokos' dalam Kolose 1:15. Penelitian ini diharapkan memberikan sumbangan tambahan untuk meningkatkan

\footnotetext{
${ }^{6}$ N N, "Apakah Yesus benar-benar Putra Sulung Allah ?," dalam Majalah Sadarlah, Maret (Jakarta: Saksi-Saksi Yehuwa Indonesia, 2016), 12.

7 N N, "Mengapa Yesus disebut Putra Allah?," www.jw.org, Saksi-Saksi Yehuwa, 2013, https://www.jw.org/id/perpustakaan/majalah/wp20130301/yesus-putra-allah/.

8 N N, "Kenalilah "Pikiran Kristus"," www.jw.org, Menara Pengawal, 15 Februari 2000, https://www.jw.org/id/perpustakaan/majalah/w20000215/Kenalilah-Pikiran-Kristus/.

9 Pangeran Manurung, "Studi Eksegetis Yohanes 1:1-18 Sebagai Apologetik Terhadap Kristologi Saksi Yehuwa," Journal Kerusso 1, no. 2 (5 September 2016): 1-41, https://doi.org/10.33856/kerusso.v1i2.49.

10 N N, "Apa Maksudnya Yesus Adalah Putra Allah?," www.jw.org, Saksi-Saksi Yehuwa, 2021, https://www.jw.org/id/ajaran-alkitab/pertanyaan/yesus-adalah-putra-allah/.

11 Dicky Dominggus, "Kedudukan Kristus Dalam Penciptaan Menurut Kolose 1:15-20 (Tanggapan Kristologi Saksi Yehuwa)," Religi: Jurnal Studi Agama-agama 16, no. 1 (26 Juni 2020), https://doi.org/10.14421/rejusta.2020.1601-03.

12 Roni Ismail, "Konsep Ketuhanan menurut Kristen Saksi Yehuwa," Jurnal Sosiologi Agama 10, no. 2 (2017): 83-108, https://doi.org/10.14421/jsa.2016.102-04.
} 
pengertian dan pemahaman para pembaca secara benar terhadap makna kata 'yang sulung atau prōtotokos' berdasarkan Kolose 1: 15.

\section{METODE}

Penelitian artikel ini menggunakan metodologi penelitian kualitatif untuk kajian biblika, dengan pendekatan secara eksegesis. Metode ini bertujuan untuk menggambarkan dan menjelaskan semua fenomena yang terdapat di dalam masalah yang diteliti, meliputi pengumpulan data dan penyusunan data serta interpretasi dan analisa tentang arti data tersebut. ${ }^{13}$ Menurut Sarantakos, metodologi kualitatif bertujuan untuk lebih menggali lebih dalam fenomena yang ada, yang berhubungan dengan studi kasus pada penelitian ini, bukan hanya menggambarkan apa yang tampak melainkan meneliti yang melatarbelakangi fenomena itu bisa terjadi. ${ }^{14}$ Menurut Nurcahyo, tujuan dari studi kasus sendiri mempelajari secara intensif tentang latar belakang masalah keadaan dan posisi suatu peristiwa yang sedang berlangsung saat ini. ${ }^{15}$ Berkenaan dengan pengertian di atas, maka kemudian penulis menempuh langkah-langkah antara lain, mempelajari isu tentang perbedaan pemahaman yang berkembang tentang kata prototokos, mengumpulkan data dari berbagai sumber pustaka tentang latar belakang dan dasar pemahaman aliran Saksi-saksi Yehuwa dalam memahami kata prototokos dalam Kolose 1: 15. Penulis juga mengumpulkan berbagai sumber pustaka dari pandangan teolog Kristen tentang pemahaman kata prototokos tersebut. Kedua kelompok padangan ini kemudian dikaji dan ditanggapi secara

\footnotetext{
13 Marlen Tineke Alakaman, "Yesus Sebagai Hamba: Kajian Kristologi Dan Relevansinya Pada Pelayan Gereja Di Jemaat GPM Nehemia Sektor Petra," KENOSIS: Jurnal Kajian Teologi 4, no. 1 (1 Desember 2018): 15-34, https://doi.org/10.37196/kenosis.v1i1.20.

14 Bayu Dardias Kurnadi, Praktek Penelitian Kualitatif: Pengalaman dari UGM (Yogyakarta: Fakultas IImu Sosial dan IImu Politik UGM, 2011), 8.

15 Dardias Kurnadi.
} 
proporsional. Langkah berikutnya adalah melakukan kajian biblika dengan menggunakan pendekatan eksegesis yang didasarkan pada keterampilan menerapkan prinsip-prinsip hermeneutika secara tepat terhadap teks alkitab menurut bahasa asli. Langkah ini bertujuan untuk menemukan dan memahami makna teks dari kata prototokos yang dimaksudkan oleh penulis. Karena itu tahap-tahap eksegesis yang dikerjakan terhadap kata prototokos dilakukan melalui beberapa analisis, yaitu: gramatika, sintaksis, genre, konteks, bentuk literal, teologi, sejarah, maksud dan tujuan penulis surat Kolose. Untuk mempermudah proses pendekatan eksegesis sehingga memperoleh hasil yang tepat, maka penulis kemudian melakukan penyelidikan dengan menggunakan bahasa Ibrani dan Yunani sebagai bahasa asli Alkitab. Menurut John D. Grassmick, eksegesis merupakan pendekatan terbaik agar penafsir dapat menemukan makna yang dimaksudkan penulis dengan tepat. ${ }^{16}$

\section{HASIL}

Setelah melakukan peneletian dan pengkajian, maka telah diperoleh hasil bahwa istilah prōtotokos atau yang sulung dalam Kolose 1: 15 mununjuk kepada Yesus Kristus sebagai subjek atau pelaku utama dalam penciptaan dan bukan sebagai ciptaan Allah yang pertama. Pengertian prōtotokos harus dipahami berdasarkan maksud dan tujuan rasul Paulus dan ayat-ayat kontes dalam Kolose 1: 15-25, yaitu yang menjelaskan superioritas atau keunggulan Yesus Kristus atas segala ciptaan. Ini menunjuk kepada pengertian penghormatan yang dimiliki oleh Yesus. Kata prōtotokos juga memiliki kesejajaran arti yang sama dengan kata 'bekor' dalam Alkitab Perjanjian Lama, yang digunakan kepada Yakub atau Israel

16 John D. Grassmick, Prinsip-Prinsip dan Praktek Eksegesis Bahasa Yunani, trans. oleh Petrus Maryono, Diktat (Yogyakarta: STTII, 1996), 3-4. 
yang disebut sebagai 'yang sulung' (Kel. 4: 22) dan juga Efraim sebagai anak sulung Allah (Yer. 31: 9). Meskipun Yakub bukanlah 'bekor' atau anak yang sulung bagi Ishak secara lahiriah, dan Efraim bukanlah 'bekor' atau anak yang sulung bagi Yusuf. Namun istilah ini 'bekor' merupakan bentuk penghormatan dan kedudukan mereka yang diberikan Allah lebih utama dari yang lain. Kemudian dalam perkembangan sejarah penyataan secara progresif, kata 'bekor' menunjuk kepada raja Daud (Maz. 89: 28), yang secara futuristik di masa yang depan sesungguhnya digenapi atau dipenuhi dalam diri Yesus Kristus. Dengan demikian, kata prōtotokos dalam Kolose 1: 15 haruslah ditafsirkan dan dipahami berdasarkan penggunaannya pada kata 'bekor' dalam Mazmur 89: 28 yang menegaskan superioritas atau keunggulan Yesus Kristus dalam hubungan-Nya dengan Allah atas segala ciptaan. Penafsiran kata prōtotokos secara keliru akan memberikan arti seolah-olah Yesus adalah ciptaan yang pertama dari Allah sebelum segala ciptaan lain. Kesalahan ini dapat terjadi karena tiga alasan. Pertama, tidak mempertimbangkan arti konteks dari Kolose 1: 15-20. Kedua, tidak mempertimbangan latar belakang sejarah penggunaan istilah tersebut secara benar dalam Perjanjian Lama. Ketiga, sangat dipengaruhi oleh pemahaman kafir seperti gnostik. Inilah kekeliruan yang dilakukan dan dipahami oleh aliran Saksisaksi Yehuwa terhadap kata prōtotokos.

\section{PEMBAHASAN}

Paulus menulis surat kepada jemaat di Kolose dengan tujuan untuk memurnikan kembali pemahaman jemaat terhadap Kristus adalah Allah yang Mahakuasa dan Ia lebih utama dari segala sesuatu yang telah diadakan-Nya (Kol. 1: 15). Kepentingan utama dari tanggung jawab Paulus adalah meyakinkan orang- 
orang Kristen di Kolose tentang keilahian Yesus Kristus. Yesus Kristus adalah Tuhan, Dialah yang patut disembah dan Dialah yang lebih utama dari segala sesuatu dan segala sesuatu ada dibawah tangan kuasa-Nya. ${ }^{17}$ Rasul Paulus ketika menjelaskan istilah kata 'prōtotokos atau yang sulung' dalam kitab Kolose 1: 15, sesungguhnya berpangkal pada kata 'Ia adalah gambar Allah' pada ayat tersebut menunjukkan kepada kesatuan-Nya dengan Allah Bapa sejak kekekalan. ${ }^{18}$ Istilah 'gambar' (eikōn) menekankan hubungan kesatuan Kristus dengan Allah, sedangkan kata 'prōtotokos' menunjuk pada hubungannya dengan penciptaan. Jika kata prōtotokos dilepaskan dari konteksnya dan dari pernyataan rasul Paulus yang lainnya tentang Kristus, maka ungkapan ini bisa dipahami untuk memasukkan Yesus Kristus di antara suatu ciptaan. Tetapi konteks dalam kitab Kolose membuatnya menjadi jelas atau nyata, bahwa kata prōtotokos tidak bisa digunakan untuk merujuk kepada Yesus sebagai yang pertama diciptakan dari semua makhluk. ${ }^{19}$ Hal itu sesuai dengan tujuan yang hendak dicapai oleh rasul Paulus dalam surat Kolose adalah untuk memberantas ajaran palsu yang berbahaya di Kolose yang sedang menggantikan keunggulan Kristus dan kedudukan-Nya sebagai inti dalam ciptaan. ${ }^{20}$ Mengingat konteks jemaat Kolose yang terjebak untuk menyembah ciptaan dan merendahkan Kristus sebagaimana terlihat dalam Kolose 2: 16-23. ${ }^{21}$

Dalam hubungan dengan segala yang diciptakan, maka kata 'prōtotokos' merupakan bentuk kata sifat nominatif, maskulin tunggal yang menunjuk kepada

\footnotetext{
17 Stepanus Stepanus, "Keunggulan Yesus Kristus Menurut Kolose 1: 16-18," HUPERETES: Jurnal Teologi dan Pendidikan Kristen 1, no. 1 (2019): 49-61, https://doi.org/10.46817/huperetes.v1i1.16.

18 Tom Jacobs SJ, Siapa Yesus Kristus menurut Perjanjian Baru (Yogyakarta: Kanisius, 1993), 75.

19 P. O'Brien dkk., Colossians-Philemon, Word Biblical Commentary (Zondervan, 2014), 4.

20 Deky Nofa Aliyanto, "Tanggapan Terhadap Kristologi Saksi Yehuwa Kristus adalah Ciptaan Yang Pertama Berdasarkan Kolose 1:15," FIDEl: Jurnal Teologi Sistematika dan Praktika 2, no. 2 (10 Desember 2019): 244-361, https://doi.org/10.34081/fidei.v2i2.39.

${ }^{21}$ Aliyanto.
} 
pribadi Kristus sebagai subjek atau tokoh utama dalam konteks bahasan Kolose

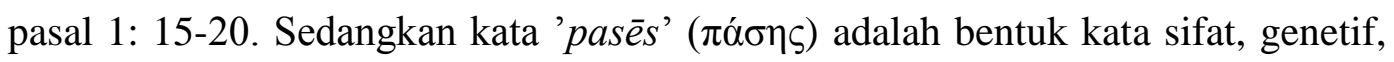

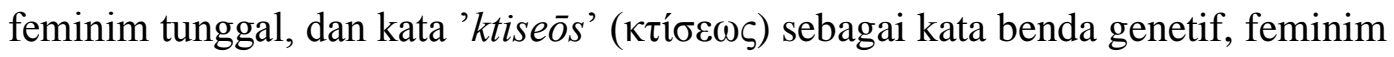
tunggal biasa. Kedua kata 'pasēs dan ktiseōs' merupakan penjelas atau yang memberikan penegasan kepada posisi kata 'prōtotokos.' Karena bentuk genetif pada frasa 'pasēs ktiseōs' menunjuk pada kata prōtotokos sebagai subjek atau pelaku utama bagi frara 'pasēs ktiseōs', maka kata prōtotokos lebih baik diterjemahkan dengan arti 'melebihi atau mengungguli segala yang diciptakan., ${ }^{22}$ Karena itu Kristus sebagai prōtotokos atau yang sulung adalah menekankan arti memiliki keunggulan melampaui segala ciptaan. Selanjutnya dalam pemikiran Ibrani dan Yunani, kata 'prōtotokos atau yang sulung' tidak menunjuk kepada sebuah pengertian yang berhubungan atau terkait dengan waktu, tetapi kata 'yang sulung' merupakan satu sebutan atau pernyataan secara umum yang menunjuk kepada pengertian penghormatan. ${ }^{23}$ Di sini kedudukan 'prōtotokos sebagai kata sifat memiliki kaitan langsung dan sejajar dengan kata ganti 'hos.' Maka dalam fungsi sintaksis pada Kolose 1: 15, kata 'prōtotokos dan hos' sama-sama bertindak sebagai pelaku utama dari frasa pasēs ktiseōs. Untuk membantu mengungkapkan makna ungkapan 'yang sulung atau prōtotokos' bagi Kristus. Tom Holland menegaskan bahwa ajaran Yesus dan Paulus memiliki hubungan yang jelas dengan Perjanjian Lama. Karena itu teologi Perjanjian Lama memainkan peran penting dalam Kristologi Paulus dan penyajian ungkapan anak sulung adalah inti dari Kristologi Paulus. Di samping itu terminologi Anak Sulung

\footnotetext{
22 B. F. Drewes, Kunci bahasa Yunani Perjanjian Baru: surat Roma hingga kitab wahyu, ed. oleh Chrisostomus Sihotang, Wilfrid Haubeck, dan Heinrich von Siebenthal (Jakarta: Gunung Mulia, 2006), 185.

23 William Barclay, Pemahaman Alkitab Setiap Hari, Surat Filipi, Kolose, 1 dan 2 Tesalonika, trans. oleh Ferdy Suleeman, Kolose (Jakarta: BPK Gunung Mulia, 2006), 182.
} 
merupakan terobosan yang sangat penting untuk mendapatkan gagasan tentang Kristologi Paulus. ${ }^{24}$

Pengertian kata prōtotokos memiliki arti yang sama dengan kata 'bekori' dalam Perjanjian Lama, dimana Israel disebut sebagai umat kesayangan Allah, sebagai anak sulung Allah. Dalam Keluaran 4: 22, dinyatakan "Beginilah firman TUHAN: Israel ialah anak-Ku, anak-Ku yang sulung (Ibrani: bekori). Juga dalam Yeremia 31: 9, "sebab Aku telah menjadi bapa Israel, Efraim adalah anak sulungKu” (Ibrani: bekori). Sebutan ini merupakan suatu bentuk penghormatan terhadap kedudukan yang diberikan oleh Allah kepada Israel dan Efraim, sehingga Allah menyebut mereka sebagai 'anak-Ku yang sulung'. Itu berarti istilah "yang sulung" tidak bisa hanya serta merta ditafsirkan secara harafiah berdasarkan urutan kelahiran seperti di dalam suatu keluarga. Sebab Yakub yang dinamai Israel secara harafiah adalah bukan anak yang sulung atau anak pertama yang dilahirkan bagi Ishak, melainkan Esau yang secara lahiriah adalah anak sulung yang dilahirkan bagi Ishak. Demikian juga Efraim bukanlah anak sulung yang dilahirkan bagi Yusuf, tetapi Manasye-lah sebagai anak sulung yang dilahirkan bagi Yusuf. Namun TUHAN menyebut Yakub dan Efraim sebagai anak-Nya yang sulung, serta bukan sebaliknya Esau dan Manasye yang disebut sebagai anak yang sulung bagi Allah. Dengan demikian, istilah 'prōtotokos atau yang sulung' pada ayat-ayat kitab suci di atas tidak menunjukkan hubungan dengan hal urutan kelahiran dalam suatu keluarga atau dalam hal urut-urutan penciptaan yang dilakukan oleh Allah. Sebaliknya, istilah yang sulung sebenarnya menunjuk

${ }^{24}$ Halim Wiryadinata, "An Understanding the Pauline Christology Significance of Firstborn (Protokos) In The Light of Paschal Theology: Critical Evaluation on Colossian 1: 15-20," Kurios 4, no. 1 (11 April 2018): 14, https://doi.org/10.30995/kur.v4i1.33. 
kepada prioritas atau keunggulan yang dimiliki oleh seseorang. Ini adalah bentuk penghormatan yang diberikan Allah kepada kepada Yakub dan Efraim.

Selanjutnya istilah 'yang sulung' digunakan sebanyak 130 kali dalam LXX (Septuaginta), terutama pada silsilah dan kisah sejarah untuk menunjukkan skala prioritas dan kedaulatan tertinggi yang dimiliki oleh seseorang. Juga sering digunakan untuk menunjuk kepada orang yang memiliki tempat khusus dalam kasih Bapa, seperti Israel yang disebut sebagai "anak-Ku yang sulung”, yang sesungguhnya merupakan sebuah ungkapan yang menekankan adanya hubungan yang sangat unik dan dekat antara Allah dan Israel. ${ }^{25}$ Kemudian, kata 'yang sulung' (Ibrani: bekor - בַּבְּר) merupakan gelar yang dijanjikan bagi Mesias yang dinubuatkan (Mzm. 89: 28). Pada konteks ini menunjuk kepada Daud, namun secara futuristik pada waktu yang akan datang sesungguhnya sebagai suatu pesan nubuatan yang akan digenapi oleh Kristus sendiri. Sebagaimana dinyatakan dalam kitab Ibrani 1: 6, dan ketika Ia membawa pula Anak-Nya yang sulung ke dunia, Ia berkata: 'Semua malaikat Allah harus menyembah Dia. ${ }^{, 26}$

Menurut Adam Clarke's kebiasaan orang-orang Yahudi menyebut Yahweh yang sulung dari seluruh dunia atau dari semua ciptaan untuk menandakan bahwa Ia telah menciptakan atau menghasilkan segala sesuatu, sehingga Kristus di sini disebut 'prōtotokos atau yang sulung' dan kata-kata yang mengikuti ayat-ayat 16 dan 17 tentang segala sesuatu yang kelihatan maupun yang tidak kelihatan telah diciptakan di dalam Dia, oleh Dia dan untuk Dia adalah menjadi buktinya. Ini ungkapan Yahudi yang diterapkan pada wujud yang

25 O'Brien dkk., Colossians-Philemon, 44.

${ }^{26}$ T.K. Abbott, A Critical and Exegetical Commentary on the Epistles to the Ephesians and to the Colossians, International critical commentary on the Holy Scriptures of the Old and New Testaments (Scribner, 1902), 210. 
tertinggi dan itu hanya untuk menunjukkan eksistensi kekal-Nya, dan untuk menunjukkan Dia sebagai penyebab segala sesuatu. Jadi sungguh tidak masuk akal jika ada orang yang menyangka bahwa rasul Paulus bermaksud untuk menyampaikan gagasan yang tidak masuk akal tentang inferioritas Yesus Kristus, sebagai pribadi yang diciptakan, terbatas keberadaan-Nya dan yang memiliki kedudukan sama dengan ciptaan yang lain karena sama-sama diciptakan. ${ }^{27}$ Namun sebaliknya bahwa sesungguhnya "Kristus adalah Tuhan". ${ }^{28}$ Ketika ungkapan yang sulung dari semua ciptaan tertanam di dalam Kristus, maka arti dari frasa ini mengacu pada prioritas waktu dan status, tetapi bukan sebagai ciptaan. Di sini, supremasi Kristus atas ciptaan telah diperkenalkan. ${ }^{29}$

Karena itu istilah 'prōtotokos atau yang sulung' dalam Kolose 1: 15 tidak boleh diartikan tanpa mempertimbangkan arti konteks dan tujuan dari penggunaan kata tersebut. Sebab jika ditafsirkan secara hurufiah tanpa mempertimbangkan konteks teks tersebut, maka istilah 'prōtotokos atau yang sulung' dapat menimbulkan pengertian yang salah. Akibatnya Kristus hanya ditafsirkan sebagai salah satu ciptaan pertama dalam alam semesta yang diciptakan oleh Allah. Tentunya pengertian ini tidak sesuai dan bertentangan dengan konteks seluruh bagian pada Kolose 1: 15-20. Robert G. Bratcher dan Eugene menambahkan pengertian 'prōtotokos' di sini tidak menunjuk bahwa Yesus sebagai ciptaan

\footnotetext{
${ }^{27}$ A. Clarke dan Parsons Technology, Adam Clarke's Commentary on the Bible, Quick Verse Library (Parsons Technology, 2000), https://books.google.co.id/books?id=M_YFPQAACAAJ.

28 O'Brien dkk., Colossians-Philemon, 45.

29 Chandra Han, "Christ's Supremacy: Colossians 1:15-20 and Its Implication in Education," Diligentia: Journal of Theology and Christian Education 1, no. 1 (30 September 2019): 1, https://doi.org/10.19166/dil.v1i1.1887.Han
} 
pertama dari Allah Bapa, tetapi menekankan kepada hubungan Yesus dengan Allah Bapa sebagai Anak yang kekal, dan sebagai pewaris Bapa yang di sorga. ${ }^{30}$

Jika kata 'prōtotokos' yang dimaksud di sini sebagai ciptaan yang sulung atau yang diciptakan pertama dari segala ciptaan lain, maka rasul Paulus seharusnya menggunakan kata prōtoktisis dan tidak menggunakan kata prōtotokos. Namun kata yang digunakan rasul Paulus dalam Kolose 1: 15 adalah prōtotokos, artinya yang sulung atau yang utama dalam skala prioritas. Karena Kata 'prōtotokos' dalam Kolose 1: 15 adalah kata atau istilah yang sangat berbeda dengan istilah prōtoktisis yang berarti 'yang pertama diciptakan.' Gagasan dari istilah prōtoktisis terlihat dalam hubungannya dengan penciptaan langit dan bumi serta segala isinya secara ex-nihilo, yaitu penciptaan dari yang tidak ada kemudian menjadi ada. Karena itu istilah prōtoktisis menyatakan bahwa langit dan bumi merupakan ciptaan yang pertama (Kej. 1; Maz. 148: 5; Kol. 1: 16). Sedangkan istilah prōtotokos dalam konteks Kolose 1: 15 hendak menyatakan fakta kekekalan dan keilahian Kristus sebagai Sang Pencipta, bukan sebagai ciptaan yang pertama dari segala yang diciptakan. ${ }^{31}$ Geisler mengemukakan hal yang sama bahwa, istilah yunani yang digunakan dalam Kolose 1: 15 adalah prōtotokos dan tidak menggunakan prōtoktisis. Secara tata bahasa kata 'prōtotokos' sesuai dengan konteks seluruh bagian utama kitab Kolose yang bertujuan untuk menunjukkan superioritas atau keunggulan Kristus di atas segala sesuatu. Karena itu kata prōtotokos sangat tidak mungkin menjadi bagian dari ciptaan. Yesus

${ }^{30}$ R.G. Bratcher dkk., Pedoman Penafsiran Alkitab: Surat-surat Paulus kepada Jemaat di Kolose dan Filemon, Pedoman Penafsiran Alkitab (Lembaga Alkitab Indonesia, 2019), 23.

${ }_{31}$ Fritz Rienecker, A Linguistic Key To The Greek New Testament (Grand Rapids: Regency Reference Library, 1980), 567. 
Kristus sendiri adalah pribadi yang menciptakan segala sesuatu dari yang tidak ada menjadi ada, yang disebut 'creatio ex nihilo., ${ }^{32}$

Sebab jika Kristus adalah ciptaan, maka tidak mungkin dia dapat menciptakan segala sesuatu dari yang tidak ada menjadi ada (creatio ex nihilo), sementara Dia sendiri adalah ciptaan. Karena itu suatu ciptaan tidak mungkin dapat menciptakan dirinya sendiri dan menciptakan segala sesuatu dari yang tidak ada kemudian menjadi ada, apabila dia sendiri adalah ciptaan. Karena itu, kata 'yang sulung atau prōtotokos' harus dimengerti dalam pengertian antara lain. Pertama, dalam pengertian 'lebih utama' daripada ciptaan, dan menekankan keberadaan Kristus yang sudah ada sebelum segala sesuatu dan bukan sebagai ciptaan yang tertua atau bagian dari ciptaan Allah yang pertama. Hal ini sangat sesuai dengan pekerjaan-Nya sebagai pencipta. Kedua, memiliki kedudukan yang 'lebih tinggi' dari segala yang diciptakan (bnd. Kol. 2: 17-18). Kedua gagasan ini sangat sesuai dengan tujuan utama dari kitab Kolose 1: 15-20 secara keseluruhan mengenai keberadaan Kristus yang terlebih dahulu ada sebelum segala sesuatu ada. Dalam hal ini rasul Paulus tidak memiliki kesan dan tidak berpikir bahwa Kristus bukanlah yang terbesar di antara sekian banyak ciptaan lainnya. Namun di sini rasul Paulus dengan jelas menempatkan posisi Kristus jauh di atas, bahkan melebihi semua ciptaan. Hal ini didukung dalam pernyataan-pernyataan berikutnya dalam Kolose 1: 16 yang mengungkapkan bahwa, segala sesuatu telah diciptakan 'di dalam Dia' (en autō), 'oleh Dia' (di autou) dan 'untuk Dia' (eis auton). Sehingga terlihat dengan jelas bahwa, rasul Paulus menempatkan Kristus Exposition of the Scriptures, Collosians (Dallas Theological Seminary: Victor Books, 1985), 672-673. 
sebagai pusat dari penciptaan dan sekaligus juga sedang menegaskan keunggulan yang dimiliki oleh Kristus melebihi segala ciptaan. ${ }^{33}$

Dalam pandangan Guthrie, bahwa dari segi waktu dan ciptaan, penggunaan kata 'yang sulung' juga menunjukkan dua prioritas yang dimiliki oleh diri Kristus yaitu Kristus mendahului seluruh ciptaan (dalam waktu) dan Kristus berdaulat atas seluruh ciptaan (dalam kedudukan atau peringkat). Karena itu ketika Yesus menyatakan diri-Nya sebagai 'yang sulung atau ho prōtotokos', itu berarti menyiratkan kedaulatan yang dimiliki oleh Yesus. ${ }^{34}$ Sehingga istilah prōtotokos mengacu kepada kedudukan atau status dalam hubungan dengan Allah. Dalam hal ini, Yesus Kristus "memiliki hak utama atau prioritas dan keunggulan" yang melebihi semua ciptaan. Yesus Kristus bukanlah makhluk ciptaan yang pertama diciptakan Allah, tetapi Dia adalah Allah yang kekal. ${ }^{35}$ Ia juga menjadi 'sebab' yang oleh-Nya seluruh ciptaan yang sebelumnya tidak ada kemudian menjadi ada dan menggunakan hak yang sulung sebagai Tuhan atas ciptaan, serta ditetapkan secara illahi sebagai "pewaris dari segala sesuatu" (Ibr.1: 2). Ia ada di sana ketika pekerjaan penciptaan dimulai dan itu adalah untuk-Nya serta melalui Dia maka semua itu telah diselesaikan. ${ }^{36}$

Dengan demikian, maka penempatan dan penafsiran istilah yang sulung (prōtotokos) dari semua ciptaan adalah sangat penting untuk pemahaman secara benar tentang konsep Kristologi rasul Paulus. Kata 'yang sulung atau prōtotokos' harus dipahami sesuai dengan maksud dan tujuan Paulus dalam surat Kolose,

${ }^{33}$ Donald Guthrie, Teologi Perjanjian Baru, vol. 3 (Jakarta: BPK Gunung Mulia, 2009), 404.

34 Guthrie.

35 Warren W. Wiersbe, The Bible Exposition Commentary; An Exposition of The new Testament Comprising the Entire "BE" Series (lllionis: Victor Books, 1989), NN.

36 W E. Vine, An Expository Dictionary of New Testament Words, Prototokos (New Jersey: Fleming H. Revell Company, 1966), 104. 
yaitu dalam pengertian 'terunggul' dan bukan dalam pengertian temporal 'sebelum kelahiran.' Pemikiran rasul Paulus juga sejalan dengan tulisan Perjanjian Baru lainnya yang menekankan kedaulatan Kristus atas dunia yang diciptakan. Dalam Injil Yohanes 1: 3 "Segala sesuatu dijadikan oleh Dia dan tanpa Dia tidak ada suatupun yang telah jadi dari segala yang telah dijadikan." Juga dalam Ibrani 1: 2 dinyatakan 'Oleh Dia Allah telah menjadikan alam semesta. $^{37}$

Untuk membenarkan keyakinan Saksi-saksi Yehuwa tentang Yesus sebagai ciptaan Allah yang pertama sebelum Allah menciptakan hal-hal lain, maka kemudian mereka menggunakan kitab Amsal 8: 22, 25 sebagai dasar untuk menafsirkan kata 'yang sulung atau prōtotokos' dalam Kolose 1: 15. Menurut mereka, ada kesamaan antara kata 'hikmat' (Ibr: qanah) dalam kitab Amsal 8: 22, 25 dengan kata 'yang sulung' (Yun: prōtotokos) dalam kitab Kolose 1: $15^{38}$ Namun jika diteliti dengan seksama maka, kata 'qanah' dalam Amsal 8: 22, 25 menyatakan hikmat hadir dalam penciptaan. Tetapi kemudian ditafsirkan sebagai 'yang pertama dari ciptaan', sehingga ini sangat memberikan arti yang jauh berbeda dari penggunaan kata 'yang sulung atau prōtotokos' digunakan Paulus dalam Kolose 1: 15 untuk menyatakan Kristus sebagai Anak, memegang hak yang sulung untuk setiap hal yang diciptakan. ${ }^{39}$

Pertanyaan yang mendesak mengenai masalah penafsiran bahwa, apakah kata kerja 'qanah' (קנח) dalam Amsal 8: 22 itu sesungguhnya berarti memperoleh atau menciptakan. Menurut Christopher A. Beetham, kata kerja 'qanah' (קנח)

\footnotetext{
${ }^{77}$ D. Guthrie, The New Bible Commentary, Colossians (New York: Guidepost, 1984), 1144. Allah?"

${ }^{38} \mathrm{~N}$, "Apakah Yesus benar-benar Putra Sulung Allah?" N, "Apa Maksudnya Yesus Adalah Putra

39 Leonard W. Andrie, The Christ Hymn of Colossians 1:15-20: Drawing From The Wisdom Tradition in Helenistic- Judaism To Tidy Up The Church at Colossae (Minnesota: University of St. Thomas, 2013), 38.
} 
dinyatakan sebanyak tiga belas kali dalam Kitab Amsal, dan semua tanpa kecuali dalam konteks masing-masing memberikan makna yaitu 'memiliki atau mendapatkan. ${ }^{40}$ Kata 'qanah' (קנח) bisa ditafsirkan sebagai 'yang memiliki' karena sejalan dengan tujuan Amsal 8 yang secara keseluruhan dimaksudkan untuk menyatakan bagaimana kewenangan hikmat itu diperbesar atau dikembangkan sehingga para pembaca boleh mengejarnya dan menyesuaikan hidup mereka dengan caranya sendiri, sehingga Yehovah (YHWH) menjadi model bagi umat-Nya. ${ }^{41}$ Jadi sesungguhnya kitab Amsal 8: 22, 25 tidak membahas tentang asal usul hikmat, tetapi hikmat ini berperan ketika Allah melakukan karya penciptaan. Point utama dari Amsal 8: 22-29 yaitu baik sebelum dan selama Allah menciptakan dunia, hikmat Allah itu selalu ada dan hadir dalam diri Allah. ${ }^{42}$ Juga pada Amsal 8: 24-25 terlihat jelas menerangkan bahwa, Yehovah itu yang memiliki hikmat pada saat Dia menciptakan segala sesuatu. ${ }^{43}$ Jadi bukan menciptakan hikmat sebagai yang sulung.

Namun menurut Leonar W. Andrie, jika dilihat antara peran hikmat dalam penciptaan berdasarkan Amsal 8: 22,25, maka secara konsep ada hubungan secara paralel antara peran hikmat dalam penciptaan dan apa yang dikaitkan dengan karya Kristus dalam Kolose 1: 15-17. Jika ini dipamahi demikian, maka hal ini dapat diterima karena semakin lebih dekat makna antara Amsal 8: 22, 25 dan Kolose 1: 15-17. ${ }^{44}$ Namun di sisi lain Bruce menyatakan, bahwa Amsal 8: 22 yang berbicara tentang kehadiran personifikasi hikmat pada penciptaan dunia,

\footnotetext{
${ }^{40}$ C.A. Beetham, Echoes of Scripture in the Letter of Paul to the Colossians, Biblical Interpretation Series (Boston: Brill, 2008), 116.

41 Beetham.

42 Beetham, 117.

43 Beetham, 119.

44 W. Andrie, The Christ Hymn of Colossians 1:15-20: Drawing From The Wisdom Tradition in Helenistic- Judaism To Tidy Up The Church at Colossae, 44.
} 
tidak dianggap oleh penulis Perjanjian Baru sebagai suatu nubuatan rinci yang dapat ditekankan untuk menghasilkan kesimpulan secara kristologis. ${ }^{45}$

Meskipun Amsal 8: 22, 25 dapat memberikan laporan yang sangat baik untuk peran Kristus bila dikaitkan dengan kosmik. Namun penggunaan istilah 'yang sulung atau prōtotokos' pada Kolose 1: 15 sesungguhnya tidak berasal dari Amsal 8: 22, 25. Jika istilah 'yang sulung' (prōtotokos) dalam Kolose 1: 15 kemudian ditafsirkan bersumber dari Amsal 8: 22, 25, maka dapat memberikan arti yang jauh berbeda dari penggunaan istilah tersebut. Karena itu Leonard W. Andrie menyatakan bahwa kata 'qanah' (קנח) dalam Amsal 8: 22, 25 tidak bisa digunakan sebagai sumber bagi kata 'yang sulung atau prōtotokos' pada Kolose 1: 15. Karena itu, merupakan suatu tindakan spekulasi yang sangat nyata jika dikatakan bahwa, rasul Paulus memiliki sumber teks sebelumnya dari Amsal 8: 22, 25 dan kemudian menjadikannya dasar untuk menafsirkan istilah 'yang sulung atau prōtotokos' pada kitab Kolose 1: 15. ${ }^{46 .}$ Dalam hal ini, Saksi- saksi Yehuwa memiliki pemahaman yang keliru dan sangat bertentangan dengan penalaran dan penjelasan maksud rasul Paulus dalam Kolose 1: 15-17.

Selanjutnya Leonard W. Andrie berpandangan bahwa, penggunaan kata 'yang sulung atau prōtotokos' oleh rasul Paulus dalam Kolose 1: 15, akan menjadi jauh lebih baik dan benar jika peran Kristus secara kosmik dihubungkan secara langsug dengan kitab Mazmur 89: 28. Karena di sana dikatakan bahwa, ”Akupun

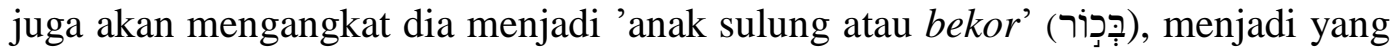

\footnotetext{
45 F.F. Bruce, The Epistles to the Colossians, to Philemon, and to the Ephesians, New International Commentary o (Grand Rapids: Eerdmans Publishing Company, 1984), 60.

46 W. Andrie, The Christ Hymn of Colossians 1:15-20: Drawing From The Wisdom Tradition in Helenistic- Judaism To Tidy Up The Church at Colossae, 40.
} 
maha tinggi di antara raja-raja bumi." ${ }^{, 47}$ Pandangan tersebut didukung oleh Gordon Fee yang menyatakan bahwa, penggunaan kata 'yang sulung' atau prōtotokos oleh rasul Paulus sangat besar kemungkinan berasal dari Mazmur 89: 28. ${ }^{48}$ Dengan kata lain, sebutan 'yang sulung' (prōtotokos) dalam Kolose 1: 15 adalah merupakan gema dari kitab Mazmur 89: 28, yang menggunakan kata

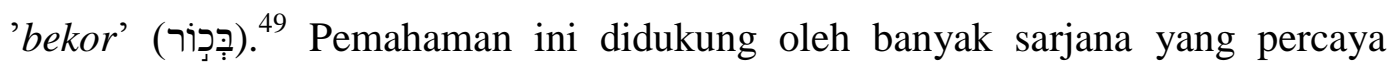
bahwa Mazmur 89: 28 adalah sumber di belakang kata 'prōtotokos atau yang sulung' dalam Kolose 1: 15. Demikian juga banyak sarjana menyetujui bahwa 'yang sulung' (prōtotokos) tidak berarti sebagai yang 'pertama diciptakan', melainkan memiliki arti yang 'unggul atau memiliki peringkat tertinggi.' Makna inilah yang ditujukan juga kepada raja Daud dalam Mazmur 89: 28, sebagai yang unggul, yang tertinggi dari antara raja-raja di bumi, dan sebagai raja yang memiliki prioritas dalam statusnya tersebut. $^{50}$ Karena itu dengan mempertimbangkan kontribusi teologisnya, maka sangatlah tepat jika Mazmur 89: 28 adalah sumber yang paling relevan dan menjadi latar belakang bagi kitab Kolose 1: 15, dan bukan bersumber dari Amsal 8: 22, 25 seperti yang dipahami oleh kelompok Saksi- saksi Yehuwa. ${ }^{51}$

Berdasarkan semua bukti pemaparan di atas kelompok Saksi-saksi Yehuwa telah menafsirkan secara keliru istilah qanah (קנח) dalam Amsal 8: 22, 25 yang berarti 'memiliki.' Kemudian menjadikan istilah qanah (קנח) tersebut sebagai dasar untuk menafsirkan istilah 'yang sulung' atau prōtotokos pada

\footnotetext{
47 W. Andrie, 40. 301.

${ }^{48}$ G.D. Fee, Pauline Christology: An Exegetical-Theological Study (Baker Publishing Group, 2007),

49 O'Brien dkk., Colossians-Philemon, 44.

50 W. Andrie, The Christ Hymn of Colossians 1:15-20: Drawing From The Wisdom Tradition in Helenistic- Judaism To Tidy Up The Church at Colossae, 38-39.

51 John Anthony Dunn, "The Regal Status of Christ in the Colossian 'Christ-Hymn,': A Re- Evaluation of the Influence of Wisdom Traditions," Trinity Evangelical Divinity School 32, no. 1 (2011): 3-18.
} 
Kolose 1: 15. Padahal konteks Amsal 8: 22, 25 adalah menekankan peran hikmat dalam penciptaan, dan tidak membicarakan hikmat sebagai ciptaan yang pertama atau yang sulung. Sedangkan istilah 'yang sulung' atau prōtotokos dalam Kolose 1: 15 menekankan skala keunggulan atau superioritas yang dimiiki oleh Yesus terhadap ciptaan.

Di sisi lain, kelompok saksi Yehuwa ketika menafsirkan dan memahami istilah prōtotokos dalam Kolose 1: 15 sangat dipengaruhi oleh paham gnostik. Dalam paham gnostik, istilah 'yang sulung' (prōtotokos) adalah menunjuk kepada "manusia pertama" yang duduk bersama dengan Tuhan di tahkta-Nya. Kemudian dalam hubungan dengan dunia keduanya dilukiskan sebagai hubungan kepala dan tubuh. Paham gnostik ini terlihat jelas dalam pandangan platoisme yang dikembangkan oleh Filo. Filo kemudian ketika menafsirkan istilah 'yang sulung' (prōtotokos) tidak mempertimbangkan arti dari konteks ayat-ayat sekitarnya, sehingga menimbulkan kesan bahwa Kristus adalah ciptaan yang pertama. ${ }^{52}$

Pada perkembangan sejarahnya, kemudian pada awal abad ke empat masehi pengaruh neo-platoisme ini berkembang dalam konsep yang agak berbeda dan menjelma kembali dalam ajaran bidat Arius yang mengajarkan bahwa Yesus sebagai Firman Allah itu adalah makhluk belaka yang telah diciptakan oleh Allah sebelum dunia dijadikan. Sesudah itu, Allah menjadikan Dia sebagai rekan atau patner kerja untuk menciptakan alam semesta. Oleh karena Yesus Kristus adalah makhluk belaka, maka tentu saja Ia diawali oleh waktu tertentu. Dalam hal ini menurut mereka bahwa, pernah ada waktu dimana firman Allah itu belum ada. ${ }^{53}$ Arius dan penerus ajarannya berpandangan bahwa, Anak bukanlah bagian

52 Guthrie, Teologi Perjanjian Baru, 404.

53 Bambang Noorsena, Haruskah Anda Percaya Kepada Saksi - Saksi Yehuwa?: Suatu Pledoi Soal Tri Tunggal (Surabaya: ISCS, 2007), 34-35. 
daripada Allah, dan tidak memiliki zat yang sama dengan Allah Bapa. Anak dijadikan oleh Allah Bapa sebelum dunia dijadikan. Maka sebelum dijadikan, sesungguhnya Anak itu tidak ada. ${ }^{54}$

Pandangan ini selanjutnya kemudian diadopsi dan kemudian turut mempengaruhi pola penafsiran dan pemahaman dari kelompok Saksi-saksi Yehuwa ketika mereka menafsirkan istilah 'yang sulung' (prōtotokos) pada Kolose 1: 15. Dalam hal ini, kelompok Saksi-saksi Yehuwa ketika menafsirkan kitab Kolose 1: 15, tidak memperhatikan prinsip-prinsip hermeneutika atau kaidah-kaidah penafsiran secara baik dan benar. Semua ini sangat memberikan andil yang cukup besar kepada pemahaman doktrin kristologi mereka yang sangat berbeda, bahkan dinilai salah dan bertentangan dengan keyakinan umat kristen selama ini.

\section{KESIMPULAN}

Terbukti bahwa penggunaan kata 'yang sulung' (prōtotokos) bagi Yesus oleh rasul Paulus dalam Kolose 1: 15 adalah berakar pada Alkitab Perjanjian Lama. Karena itu istilah 'yang sulung' (prōtotokos) hanya dapat dipahami secara benar apabila ditelusuri berdasarkan sejarah penggunaan istilah tersebut dalam Alkitab Perjanjian Lama. Penafsiran terhadap kata 'yang sulung' (prōtotokos) dalam Kolose 1: 15 yang dikenakan bagi Tuhan Yesus dapat memiliki arti yang salah, jika kata tersebut ditafsirkan tanpa mempertimbangkan konteks teks dan latarbelakang sejarah penggunaan kata 'yang sulung' (prōtotokos), serta mengabaikan maksud tujuan penulisan rasul Paulus. Penafsiran dan pemahaman kelompok Saksi-saksi Yehuwa terhadap kata 'yang sulung' (prōtotokos) dalam

54 Harun Hadiwijono, Iman Kristen (Jakarta: BPK Gunung Mulia, 2007), 310. 
Kolose 1: 15 sangat berbeda, bahkan dinilai bertentangan dengan keyakinan kristen selama ini. Dasar yang melatarbelakangi perbedaan penafsiran dan pemahaman ini disebabkan oleh tiga hal utama. Pertama, kelompok Saksi-saksi Yehuwa dalam menafsirkan kata 'yang sulung' (prōtotokos) memiliki dasar penafsiran dari istilah qanah (קנח) dalam Amsal 8: 22, 25. Padahal istilah qanah (קנח) sesungguhnya bukan bersifat Kristologi. Bahwa istilah qanah sangat berbeda

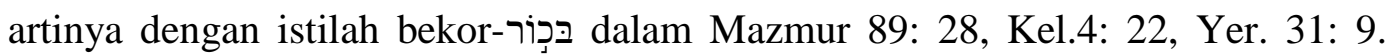
Sebaliknya keyakinan Kristiani dalam menafsirkan istilah 'yang sulung' (prōtotokos) adalah didasarkan kepada latar belakang penggunaan istilah bekorרִָּ karena dinilai bahwa istilah tersebut memiliki kesejajaran atau kesamaan makna dengan kata 'yang sulung' (prōtotokos) yang digunakan rasul Paulus dalam Kolose 1: 15. Kedua, kelompok Saksi-saksi Yehuwa dalam menafsirkan kata 'yang sulung' (prōtotokos) sangat dipengaruhi dan diadopsi dari pemahaman gnostik yang bertentangan dengan ajaran dan pemahaman kristen. Ketiga, kelompok Saksi-saksi Yehuwa dalam menafsirkan kata 'yang sulung' (prōtotokos) pada Kolose 1: 15 sama sekali tidak mempertimbangkan arti berdasarkan ayat-ayat konteks dekat (ay. 16-20) yang dapat memberikan penguatan penjelasan bagi pemahaman arti dan tujuan rasul Paulus ketika menggunakan kata 'yang sulung' (prōtotokos) dalam tulisannya. Dalam hal ini mereka mengabaikan prinsip-prinsip dasar penafsiran atau prinsip-prinsip hermeneutika secara benar. Inilah yang kemudian menimbulkan pemahaman dan keyakinan Kristologi yang sangat berbeda dan bertentangan dengan keyakinan umat Kristen pada umumnya. Sehingga berakibat hubungan yang tidak harmonis antara kelompok Saksi-saksi Yehuwa dengan semua lembaga gerejawi di 
Indonesia. Melalui tulisan ini juga diusulkan supaya adanya penelitian lanjutan tentang pemahaman Kristologi Saksi-saksi Yehuwa terhadap ungkapan 'yang sulung' berkaitan dengan kebangkitan Yesus.

\section{DAFTAR PUSTAKA}

A. Evans, Craig. Merekayasa Yesus. Yogyakarta: ANDI, 2007.

Abbott, T.K. A Critical and Exegetical Commentary on the Epistles to the Ephesians and to the Colossians. International critical commentary on the Holy Scriptures of the Old and New Testaments. Scribner, 1902.

Alakaman, Marlen Tineke. "Yesus Sebagai Hamba: Kajian Kristologi Dan Relevansinya Pada Pelayan Gereja Di Jemaat GPM Nehemia Sektor Petra." KENOSIS: Jurnal Kajian Teologi 4, no. 1 (1 Desember 2018): 1534. https://doi.org/10.37196/kenosis.v1i1.20.

Aliyanto, Deky Nofa. "Tanggapan Terhadap Kristologi Saksi Yehuwa Kristus adalah Ciptaan Yang Pertama Berdasarkan Kolose 1:15.” FIDEI: Jurnal Teologi Sistematika dan Praktika 2, no. 2 (10 Desember 2019): 244-361. https://doi.org/10.34081/fidei.v2i2.39.

Anthony Dunn, John. "The Regal Status of Christ in the Colossian "ChristHymn,': A Re- Evaluation of the Influence of Wisdom Traditions." Trinity Evangelical Divinity School 32, no. 1 (2011): 3-18.

Barclay, William. Pemahaman Alkitab Setiap Hari, Surat Filipi, Kolose, 1 dan 2 Tesalonika. Diterjemahkan oleh Ferdy Suleeman. Kolose. Jakarta: BPK Gunung Mulia, 2006.

Beetham, C.A. Echoes of Scripture in the Letter of Paul to the Colossians. Biblical Interpretation Series. Boston: Brill, 2008.

Bratcher, R.G., E.A. Nida, H. Ugang, M.K. Sembiring, E.A. Kotynski, dan L.A. Indonesia. Pedoman Penafsiran Alkitab: Surat-surat Paulus kepada Jemaat di Kolose dan Filemon. Pedoman Penafsiran Alkitab. Lembaga Alkitab Indonesia, 2019.

Bruce, F.F. The Epistles to the Colossians, to Philemon, and to the Ephesians. New International Commentary o. Grand Rapids: Eerdmans Publishing Company, 1984.

Clarke, A. dan Parsons Technology. Adam Clarke's Commentary on the Bible. Quick Verse Library. Parsons Technology, 2000. https://books.google.co.id/books?id=M_YFPQAACAAJ. 
D. Grassmick, John. Prinsip-Prinsip dan Praktek Eksegesis Bahasa Yunani. Diterjemahkan oleh Petrus Maryono. Diktat. Yogyakarta: STTII, 1996.

Dardias Kurnadi, Bayu. Praktek Penelitian Kualitatif: Pengalaman dari UGM. Yogyakarta: Fakultas Ilmu Sosial dan Ilmu Politik UGM, 2011.

Dominggus, Dicky. "Kedudukan Kristus Dalam Penciptaan Menurut Kolose 1:1520 (Tanggapan Kristologi Saksi Yehuwa)." Religi: Jurnal Studi Agama$\begin{array}{llllll}\text { agama } 16, \quad \text { no. } & 1 & & \end{array}$ https://doi.org/10.14421/rejusta.2020.1601-03.

Drewes, B. F. Kunci bahasa Yunani Perjanjian Baru: surat Roma hingga kitab wahyu. Disunting oleh Chrisostomus Sihotang, Wilfrid Haubeck, dan Heinrich von Siebenthal. Jakarta: Gunung Mulia, 2006.

E. Vine, W. An Expository Dictionary of New Testament Words. Prototokos. New Jersey: Fleming H. Revell Company, 1966.

Fee, G.D. Pauline Christology: An Exegetical-Theological Study. Baker Publishing Group, 2007.

Guthrie, D. The New Bible Commentary. Colossians. New York: Guidepost, 1984.

Guthrie, Donald. Teologi Perjanjian Baru. Vol. 3. Jakarta: BPK Gunung Mulia, 2009.

Hadiwijono, Harun. Iman Kristen. Jakarta: BPK Gunung Mulia, 2007.

Han, Chandra. "Christ's Supremacy: Colossians 1:15-20 and Its Implication in Education." Diligentia: Journal of Theology and Christian Education 1, no. 1 (30 September 2019): 1. https://doi.org/10.19166/dil.v1i1.1887.

Herlianto. Saksi-Saksi Yehuwa; Tamu tak diundang yang rajin berkunjung ke rumah-rumah. Bandung: Kalam Hidup, 2004.

Ismail, Arifuddin. "The Contradiction of the Presence of Jehovah's Witnesess as Christian Denomination in Yogyakarta." Analisa 19, no. 2 (7 Desember 2012): 171. https://doi.org/10.18784/analisa.v19i2.164.

Ismail, Roni. "Konsep Ketuhanan menurut Kristen Saksi Yehuwa." Jurnal Sosiologi Agama 10, no. 2 (2017): 83-108. https://doi.org/10.14421/jsa.2016.102-04.

Jacobs SJ, Tom. Siapa Yesus Kristus menurut Perjanjian Baru. Yogyakarta: Kanisius, 1993.

Manurung, Pangeran. "Studi Eksegetis Yohanes 1:1-18 Sebagai Apologetik Terhadap Kristologi Saksi Yehuwa." Journal Kerusso 1, no. 2 (5 September 2016): 1-41. https://doi.org/10.33856/kerusso.v1i2.49. 
N, N. “Apa Maksudnya Yesus Adalah Putra Allah?” Www.jw.org. Saksi-Saksi Yehuwa, 2021. https://www.jw.org/id/ajaran-alkitab/pertanyaan/yesusadalah-putra-allah/.

“Apakah Yesus benar-benar Putra Sulung Allah?” Dalam Majalah Sadarlah, Maret., 12. Jakarta: Saksi-Saksi Yehuwa Indonesia, 2016.

. "Kenalilah "Pikiran Kristus"." Www.jw.org. Menara Pengawal, 15

Februari

2000.

https://www.jw.org/id/perpustakaan/majalah/w20000215/Kenalilah-

Pikiran-Kristus/.

—. "Mengapa Yesus disebut Putra Allah?” Www.jw.org. Saksi-Saksi Yehuwa, 2013. https://www.jw.org/id/perpustakaan/majalah/wp20130301/yesus-putraallah/.

Noorsena, Bambang. Haruskah Anda Percaya Kepada Saksi - Saksi Yehuwa?: Suatu Pledoi Soal Tri Tunggal. Surabaya: ISCS, 2007.

O’Brien, P., D.A. Hubbard, G.W. Barker, R.P. Martin, dan J.D.W. Watts. Colossians-Philemon. Word Biblical Commentary. Zondervan, 2014.

Rienecker, Fritz. A Linguistic Key To The Greek New Testament. Grand Rapids: Regency Reference Library, 1980.

Stepanus, Stepanus. "Keunggulan Yesus Kristus Menurut Kolose 1: 16-18." HUPERETES: Jurnal Teologi dan Pendidikan Kristen 1, no. 1 (2019): 4961. https://doi.org/10.46817/huperetes.v1i1.16.

Stott, John. Kristus Yang Tiada Tara. Surabaya: Momentum, 2007.

Tim Redaksi LLB. Bagaimana Menghadapi Saksi Yehuwa, t.t.

W. Andrie, Leonard. The Christ Hymn of Colossians 1:15-20: Drawing From The Wisdom Tradition in Helenistic- Judaism To Tidy Up The Church at Colossae. Minnesota: University of St. Thomas, 2013.

Walvoord, J.F., R.B. Zuck, dan Norman L. Geisler. The Bible Knowledge Commentary: An Exposition of the Scriptures. Collosians. Dallas Theological Seminary: Victor Books, 1985.

Wiersbe, Warren W. The Bible Exposition Commentary; An Exposition of The new Testament Comprising the Entire "BE" Series. Illionis: Victor Books, 1989.

Wiryadinata, Halim. "An Understanding the Pauline Christology Significance of Firstborn (Protokos) In The Light of Paschal Theology: Critical Evaluation on Colossian 1: 15-20." Kurios 4, no. 1 (11 April 2018): 14. https://doi.org/10.30995/kur.v4i1.33. 